\title{
KINERJA AGRIBISNIS KOMODITAS PERTANIAN: KEMAMPUAN PENCIPTAAN OUTPUT, NILAI TAMBAH DAN KETERKAITAN ANTAR SEKTOR (ANALISIS KOMPARASI IO TAHUN 2005 DAN 2010)
}

\author{
THE AGRIBUSINESS PERFORMANCE OF THE AGRICULTURAL COMMODITY: \\ CAPABILITIES IN OUTPUT CREATION, ADDED VALUE AND LINKAGES AMONG SECTORS \\ (COMPARATIVE ANALYSIS OF I-O IN THE YEARS OF 2005 AND 2010)
}

\author{
Supena Friyatno ${ }^{* 1}$ dan Saptana*) \\ *) Pusat Sosial Ekonomi dan Kebijakan Pertanian \\ Jl. Tentara Pelajar No 3B Komplek Kampus Pertanian, Cimanggu, Bogor 16111
}

\begin{abstract}
In the perspective of agribusiness, the agricultural commodity has become an economic entity for the actors of businesses to develop the integration of products from upstream to downstream. This paper aimed to analyze any agricultural commodity that had grown into agribusiness commodities in the period 2005 and 2010. The methodology used was to conduct a comparative table of I-O in 2005 and 2010 to identify any agricultural commodity that had: (a) the capability in the creation of high economy through the creation of output; (b) the creation of high added value, and (c) the forward and backward relationships. Growing an agricultural commodity that has been cultivated, the higher the forward and backward linkages with other sectors. Similarly, when the ability of an agricultural commodity in creating added value is higher, the ability in creating economic value is also higher. The results showed that the groups of food commodities had lower capabilities as agricultural commodities compared with the groups of horticulture, plantation, and livestock commodities. The development of primary agricultural commodities into final products can enhance the role of agribusiness commodities. The implication is that the development of downstream industries for the commodities of food, horticulture, plantation and livestock is a strategic step in the creation of output, value added and linkages among the economic sectors.
\end{abstract}

Keywords: agribusiness, agricultural commodities, linkages between sectors, output, added value

\begin{abstract}
Abstrak: Dalam perspektif agribisnis komoditas pertanian tersebut sudah menjadi entitas ekonomi bagi pelaku usaha sehingga terbangun keterpaduan produk dari hulu hingga hilir. Tulisan ini bertujuan menganalisis komoditas pertanian apa saja yang telah berkembang menjadi komoditas agribisnis pada periode 2005 dan 2010. Metodologi yang digunakan adalah melakukan komparasi tabel I-O pada tahun 2005 dan tahun 2010 untuk mengidentifikasi komoditas pertanian apa saja yang memiliki: (a) kemampuan penciptaan ekonomi tinggi melalui penciptaan output; (b) penciptaan nilai tambah tinggi, dan (c) keterkaitan ke depan dan ke belakang. Semakin berkembang suatu komoditas pertanian yang sudah diusahakan, maka semakin tinggi keterkaitan kedepan dan kebelakang dengan sektor lain. Demikian pula, semakin tinggi kemampuan suatu komoditas pertanian dalam menciptakan nilai tambah maka akan semakin tinggi pula dalam menciptakan nilai ekonomi. Hasil kajian menunjukkan bahwa kelompok komoditas pangan memiliki kapasitas sebagai komoditas agribisnis yang lebih rendah dibandingkan dengan kelompok komoditas hortikultura, perkebunan, dan peternakan. Pengembangan komoditas pertanian primer menjadi produk akhir dapat meningkatkan peranan komoditas tersebut sebagai komoditas agribisnis. Implikasinya adalah pengembangan industri hilir (hilirisasi) baik untuk komoditas pangan, hortikultura, perkebunan, dan peternakan merupakan langkah strategis dalam penciptaan output, nilai tambah dan keterkaitan antar sektor ekonomi.
\end{abstract}

Kata kunci: agribisnis, keterkaitan antar sektor, komoditas pertanian, nilai tambah output

\footnotetext{
${ }^{1}$ Corresponding author:

Email: saptono_07@yahoo.co.id
} 


\section{PENDAHULUAN}

Perubahan lingkungan strategis berupa globalisasi ekonomi-liberalisasi perdagangan, urbanisasi dan fenomena segmentasi pasar, perubahan preferensi konsumen, serta kelestarian lingkungan menuntut adanya perubahan cara pandang dalam pembangunan pertanian. Perspektif agribisnis yang dipelopori Davis dan Goldberg (1957) merupakan salah satu gagasan fenomenal dalam bidang ekonomi pertanian. Konsep agribisnis merupakan gagasan yang diterima secara luas pada periode 1960-1980, bahkan berlanjut hingga awal 2000-an (Simatupang, 2015). Istilah agribusiness didasarkan paralelisme dengan kata agriculture, yang bermakna bisnis di bidang pertanian. Peran komoditas pertanian ke depan dapat diletakkan dalam empat peran penting, yaitu dalam penyediaan pangan $(f o o d)$, pakan ternak (feed), energi (bio-fuel), dan serat (fiber).

Sektor pertanian memiliki peran strategis yang meliputi: (a) pembentukan Produk Domestik Bruto (PDB); (b) penyedia lapangan kerja dan kesempatan berusaha melalui kegiatan produksi dan distribusi; (c) sumber devisa negara, baik melalui kegiatan ekspor maupun substitusi impor; (d) pemasok bahan makanan terhadap sektor-sektor ekonomi lainnya; (e) pemasok bahan baku untuk industri pengolahan hasil pertanian; (f) penyedia surplus bagi sektor-sektor ekonomi lainnya; dan (g) penghasil marketable surplus yang dapat meningkatkan permintaan penduduk perdesaan terhadap produksi sektor ekonomi lainnya.

Indonesia masih menghadapi beberapa masalah mendasar dalam pembangunan ekonomi, yaitu masalah kurangnya ketersediaan infrastruktur di perdesaan, pengangguran dan kemiskinan, pertumbuhan ekonomi yang kurang berkualitas, serta makin melebarnya kesenjangan pendapatan. Hasil studi di beberapa negara, sperti Nigeria, China dan Congo, menunjukkan bahwa kondisi infrastruktur jalan dan sistem transportasi di perdesaan berpengaruh positif terhadap kinerja pembangunan pertanian (Ajiboye and Afolayan, 2009; Kasali et al. 2012; Usman, 2014; Ikejiofor and Ali, 2014; Adefila and Bulus, 2014; Adedeji et al. 2014). Beberapa hasil studi empiris menunjukkan bahwa pembangunan infrastruktur jalan di perdesaan berpengaruh positif terhadap peningkatan produksi dan produktivitas hasil pertanian (Ahmed and Donovan, 1992; Yoshino and Nakahigashi, 2000a and 2000b; Gibson and Olivia, 2008; Inoni and Omotor, 2009; Ulimwengu et al. 2009; Hartono, et al. 2010; Llanto, 2012; Hartoyo, 2013;
Kiprono and Matsumoto, 2014; Suryani, 2015). Hasil penelitian menunjukkan bahwa kondisi infrastruktur irigasi dapat memengaruhi produksi dan produktivitas pertanian, tingkat efisiensi keuntungan usahatani, meningkatkan frekuensi tanam, dan meningkatkan pendapatan rumah tangga (Agustian, 2012; Rachmina et al. 2014).

Beberapa hasil studi tersebut memberikan dorongan yang lebih besar untuk lebih menempatkan kekuatan agribisnis bagi pembangunan ekonomi wilayah dan nasional. Pembangunan sektor pertanian dipandang memiliki kemampuan khusus dalam memadukan pertumbuhan dan pemerataan (growth with equity) (Baharsyah, 2007). Hal ini didasarkan pada kenyataan bahwa Indonesia memiliki keunggulan komparatif yang cukup baik untuk menghasilkan berbagai komoditas pertanian. Kinerja agribisnis secara makro dapat diukur dari penciptaan output, penciptaan nilai tambah, dan keterkaitan antar sektor ekonomi baik keterkaitan ke depan maupu keterkaitan kebelakang.

Terlepas dari strategisnya pengembangan komoditas pertanian, masih banyak kendala dan tantangan ke depan yang harus dihadapi. Permasalahan pokok pengembangan agribisnis pada komoditas pertanian dari aspek produksi adalah belum terwujudnya ragam, kualitas, kesinambungan pasokan, dan kuantitas yang sesuai dengan dinamika permintaan pasar dan preferensi konsumen. Permasalahan tersebut nampak nyata pada produk pertanian untuk tujuan pasar konsumen institusi (hotel, restaurant, rumah sakit, perusahaan-perusahaan), pasar modern dan pasar ekspor. Pendekatan permasalahan melalui analisis I-O (Input-Output) dua titik waktu 2005 dan 2010 dapat mengidentifikasi sektor atau komoditas pertanian yang dapat dibangkitkan menjadi komoditas agribisnis.

Posisi ilmiah penelitian ini diharapkan dapat menunjukkan lebih detail dari kemampuan suatu komoditas dari kelompok pangan, hortukultura, perkebunan dan peternakan, untuk menguatkan penelitian sebelumnya. Misalnya mendukung penelitian yang telah dilakukan oleh Chandra dan Asmara (2012) yang membandingkan kemampuan penciptaan output antara sektor pertanian dan sektor-sektor infrastruktur. Tujuan tulisan ini adalah (1) menganalisis komoditas/ sektor yang memiliki kemampuan dalam penciptaan nilai ekonomi melalui penciptaan output dan nilai tambah, (2) menganalisis sumber pembentukan utama pengganda output, dan (3) menganalisis keterkaitan 
komoditas/sektor dengan sektor lain ke belakang (backward linkage) sebagai penarik berkembangnya sektor lain dan keterkaitan ke depan (forward linkage) sebagai pendorong berkembangkan sektor lain.

\section{METODE PENELITIAN}

Peneltian ini difokuskan pada lokasi-lingkup nasional. Waktu penelitian dilaksanakan pada tahun 2016 dengan menggunakan dua titik waktu tahun 2005 dan 2010. Jenis data yang digunakan adalah data sekunder berupa Tabel I-O yang bersumber dari Kantor Badan Pusat Statistik Jakarta. Untuk mengetahui dinamika kinerja ekonomi digunakan dua titik waktu data Tabel I-O terbaru dan tersedia di BPS, yaitu Tabel I-O tahun 2005 dan I-O 2010. Penelitian ini menggunakan data utama Tabel I-O Indonesia tahun 2005 dan 2010. Data-data pendukung terkait dengan penelitian ini bersumber dari Badan Pusat Statistik Indonesia (BPS, 2011).

Analisis kinerja industri perkebunan kelapa sawit dilakukan dengan pendekatan deskriptif kuantitatif menggunakan teknik tabulasi dan gambar. Pendekatan yang digunakan West (1993), tersebut untuk menghitung peranan ekonomi suatu komoditas atau sektor di gunakan analisis I-O. Karena perubahan output suatu sektor adalah disebabkan oleh terjadinya perubahan permintaan akhir, sebagai akibat dari pertumbuhan ekonomi maka dengan I-O analisis dapat dihitung perubahan produksi, pendapatan dan tenaga kerja jika pemerintah atau pihak lain melakukan perubahan yang menyebabkan perubahan permintaan akhir. Formula yang dapat digunakan adalah sebagai berikut:

$$
\mathrm{AX}+\mathrm{Y}=\mathrm{X}
$$

Keterangan: $\mathrm{A}=\left(\mathrm{a}_{\mathrm{ij}}\right)$ (matrik direct coeficient); $\mathrm{X}$ = Output (Income dan penyerapan tenaga kerja); Y (Permintaan akhir).

Selain itu, untuk melihat kinerja sektor dapat dilihat dari sejauhmana keterkaitan sektor, khususnya pertanian baik terhadap industri hulu maupun hilirnya. Analisis keterkaitan terhadap sektor hilirnya disebut analisis keterkaitan sektor ke depan dan keterkaitan dengan sektor hulunya disebut analisis keterkaitan kebelakang. Analisis ini sudah banyak dilakukan seperti oleh Daryanto (1999), Syafa'at dan Friyatno (2000), Rachman (1993), Tapadas dan Dahl (1999).
Asumsi-asumsi dasar yang digunakan dalam data I-O adalah (1) keseragaman (homogenity), yaitu asumsi bahwa setiap sektor ekonomi hanya memproduksi satu jenis barang dan jasa; (2) kesebandingan (proportionality), yaitu asumsi bahwa hubungan antara input dan output pada setiap sektor merupakan fungsi linier; dan (3) penjumlahan (additivity), yaitu asumsi bahwa total efek dari kegiatan produksi di berbagai sektor merupakan penjumlahan dari efek pada masingmasing kegiatan (BPS, 1995). Namun, di sisi lain I-O memiliki kelebihan yaitu mampu menangkap dampak perubahan eksogen secara holistik pada seluruh sektorsektor yang ada dengan menggunakan Leontief inverse matrix (Terosa et al. 2000).

Karena Tabel I-O adalah merupakan keseimbangan penawaran dan permintaan, maka (BPS, 1995; Miller dan Blair, 1985; Bulmer-Thomas, 1982; Miernyk, 1965), merumuskan secara matematis sebagai berikut:

$$
\mathrm{X}_{\mathrm{i}}=\mathrm{A}_{\mathrm{i}}+\mathrm{F}_{\mathrm{i}}
$$

Keterangan: $X_{i}$ (Produksi sektor i); $A_{i}$ (Jumlah permintaan antara terhadap produksi sektor ke i); $F_{i}$ (Jumlah permintaan akhir terhadap produksi sektor ke i)

Apabila pada perekonomian suatu negara (Indonesia) terdiri dari n sektor, maka permintaan antara terhadap sektor ke i adalah merupakan penjumlahan dari input antara sektor ke i oleh sektor-sektor ke 1 sampai dengan sektor ke n:

$$
\mathrm{A}_{\mathrm{ij}}=\mathrm{A}_{\mathrm{i} 1}+\mathrm{A}_{\mathrm{i} 2}+\mathrm{A}_{\mathrm{i} 3}+\ldots+\mathrm{A}_{\mathrm{in}}=\sum_{j=1}^{n} A_{\mathrm{ij}}
$$

Keterangan: $A_{i j}$ (jumlah produksi sektor ke i yang digunakan oleh sektor ke $\mathrm{j}$ )

Total input $\left(\mathrm{X}_{\mathrm{j}}\right)$ adalah merupakan penjumlahan dari input antara dan input primer, yang pada prinsipnya harus sama dengan jumlah outputnya. Oleh karena itu, hasil bagi dari masing-masing komponen input antara dengan jumlah output atau jumlah input $\left(\mathrm{X}_{\mathrm{j}}\right)$ disebut koefisien input antara $\left(\mathrm{a}_{\mathrm{ij}}\right)$, dapat diperoleh dengan rumus :

$$
\mathrm{a}_{\mathrm{ij}}=\frac{A_{j}}{X_{j}}
$$

Keterangan: $\mathrm{a}_{\mathrm{ij}}$ (koefisien input antara, $\sum_{j=1}^{n} a_{j}=1$ ) 
Jika persamaan (3) dimasukan kedalam persamaan (4), maka persamaan masing-masing sektor adalah sebagai berikut :

$a_{11} X_{1}+a_{12} X_{2}+a_{13} X_{3}+F_{1}=X_{1}$

$a_{21} X_{1}+a_{22} X_{2}+a_{23} X_{3}+F_{2}=X_{2}$

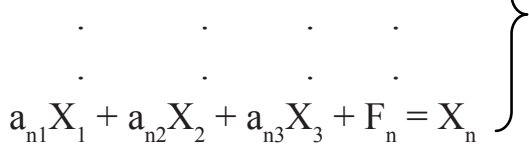

Apabila persamaan (5) diformulasikan dalam bentuk matrik, maka persamaannya menjadi sebagai berikut :

$$
\underbrace{\left[\begin{array}{cccc}
a_{11} & a_{12} & \cdot & a_{1 k} \\
a_{21} & a_{22} & \cdot & a_{2 k} \\
\cdot & \cdot & \cdot & \cdot \\
a_{n 1} & a_{n 2} & \cdot & a_{n k}
\end{array}\right]}_{\mathrm{A}} \underbrace{\left[\begin{array}{c}
X_{1} \\
X_{2} \\
\cdot \\
X_{n}
\end{array}\right]}_{\mathrm{X}}+\underbrace{\left[\begin{array}{c}
F_{1} \\
F_{2} \\
\cdot \\
F_{n}
\end{array}\right]}_{\mathrm{F}}=\underbrace{\left[\begin{array}{c}
X_{1} \\
X_{2} \\
\dot{X_{n}}
\end{array}\right]}_{\mathrm{X}}
$$

Dengan demikian dapat ditulis dalam notasi matrik sebagai berikut:

$$
\mathrm{AX}+\mathrm{F}=\mathrm{X}
$$

Keterangan: A (Matrik koefisien input antara); X ( Vektor output seluruh sektor); F (Vektor permintaan akhir); F = X-AX; F = [I-A ] X; X = F/ [I-A ]; X = (1/ [I-A]) F; $\mathrm{X}=[\mathrm{I}-\mathrm{A}]^{-1} \mathrm{~F} ;[\mathrm{I}-\mathrm{A}]^{-1}$ (Koefisien Leontiefl koefisien penggada/matrik kebalikan).

Untuk menghitung sejauhmana dampak investasi pada kelapa sawit dalam pembentukan output, pendapatan dan nilai tambah sebagai dampak dari perubahan permintaan akhir maka dengan mudah menggunakan bilangan-bilangan pengganda (multiplier) tersebut, yaitu dengan cara mengalikan koefisien Leontief (I-A) ${ }^{-1}$ dengan dengan permintaan akhir (F) untuk memperoleh perubahan besaran output $(\mathrm{X})$ atau variable makro lainnya.

Secara matematis hubungan persamaan permintaan akhir dengan nilai tambah dapat dijabarkan $\mathrm{T}=\breve{\mathrm{T}} \mathrm{X}$ dengan $\mathrm{T}$ (matrik nilai tambah); $\breve{\mathrm{T}}$ (matrik diagonal koefisien nilai Output, pendapatan dan nilai tambah); $\mathrm{X}$ $=(\mathrm{I}-\mathrm{A})^{-1} \mathrm{~F}$.

Untuk melihat sejauhmana peranan kelapa sawit sebagai trigger sektor lain, maka Rachman (1993), telah memformulasikan sebagai berikut : a. Keterkaitan langsung ke belakang (direct backward linkage)

$\mathrm{DB}_{\mathrm{j}}=\frac{\sum_{i=1}^{n} X_{j}}{X_{j}}=\sum_{i=1}^{n} a_{i j} ;$ untuk $\mathrm{j}=1,2, \ldots \mathrm{n}$

Keterangan: $\mathrm{DB}_{\mathrm{j}}\left(\right.$ Keterkaitan langsung ke belakang); $\mathrm{X}_{\mathrm{ij}}$ (Banyaknya output sektor ke-i yang digunakan sebagai input oleh sektor ke-j untuk menghasilkan output sebesar $\mathrm{X}_{\mathrm{j}}$ ); $\mathrm{X}_{\mathrm{j}}\left(\right.$ Output sektor ke-j); $\mathrm{a}_{\mathrm{ij}}$ (Matrik koefisien input antara)

b. Keterkaitan langsung ke depan (direct forward linkage)

$\mathrm{DF}_{\mathrm{i}}=\frac{\sum_{j=1}^{n} X_{i j}}{X_{j}}=\sum_{j=1}^{n} a_{i j} ;$ untuk $\mathrm{i}=1,2, \ldots . \mathrm{n}$

Keterangan: $\mathrm{DF}_{\mathrm{j}}$ (Keterkaitan langsung ke depan); $\mathrm{X}_{\mathrm{ij}}$ (Jumlah output sektor ke-i yang digunakan sebagai input oleh sektor ke-j untuk menghasilkan output sebesar $\mathrm{X}_{\mathrm{i}}$ ); $\mathrm{X}_{\mathrm{i}}$ (Total permintaan output sektor ke-i (sektor antara dan akhir)); $\mathrm{a}_{\mathrm{ij}}$ (Matrik koefisien input antara)

\section{Hipotesis}

Kemampuan suatu sektor atau komoditas pertanian yang diduga memiliki kemampuan penciptaan output dan nilai tambah adalah komoditas yang memiliki keterkaitan yang luas baik keterkaitan ke belakang maupun ke depan. Hal ini dilandasi sektor atau komoditas yang memiliki keterkaitan yang luas dapat menciptakan kesempatan kerja dan kesempatan berusaha, output, nilai tambah, dan meningkatkan konsumsi masyarakat.

Dalam sistem neraca ekonomi bahwa nilai ekonomi nasional adalah nilai dari seluruh barang dan jasa yang dirinci dari sektor-sektor dan atau komoditas ekonomi, hal ini disebut Output, dan setiap output dari suatu komoditas/sektor tentu digunakan habis digunakan oleh sektor lain baik sebagai input antara maupun untuk kebutuhan lain (permintaan akhir = final demand), serta nilai tambah yang meliputi upah, sewa, pajak dan laba (Simatupang dan Friyatno, 2016) sehingga Output=Input (BPS, 2015).

Suatu komoditas dikatakan memiliki prospek agribisnis apabila komoditas tersebut memiliki kemampuan untuk menciptakan output dan nilai tambah yang 
tinggi ketika terjadi perubahan permintaan akhir. Perubahan ini dicerminkan oleh peningkatan produksi atau output sektor-sektor ekonomi yang disebabkan adanya perubahan permintaan terhadap sektor tersebut. Sektor agroindustri memiliki keterkaitan ke depan dan ke belakang yang kuat dengan sektor-sektor lainnya. Secara skematis hubungan antara perubahan permintaan akhir dengan peningkatan output dan nilai tambah dalam system input-output dapat disimak pada Gambar 1 .

\section{HASIL}

\section{Pengganda (Multiplier) dalam Penciptaan Output dan Nilai Tambah}

Sektor pertanian mempunyai efek pengganda yang besar terkait dengan adanya keterkaitan ke depan dan ke belakang dengan sektor-sektor ekonomi lainnya, terutama industri pengolahan dan jasa. Hasil analisis angka pengganda dalam penciptaan output dan nilai tambah di Indonesia untuk kelompok komoditas tanaman pangan dan hortikultura dapat disimak pada Tabel 1.

Kelompok tanaman pangan dan hortikultura yang memiliki kemampuan dalam penciptaan output adalah ubi jalar, ubi kayu, kacang tanah, kedelai dan kacang-kacangan lainnya. Hal ini ditunjukkan oleh ada peningkatan kemampuan pengganda output dari tahun 2005 ke tahun 2010. Perubahan angka pengganda output positif berkisar antara 0,34-0,43. Angka pengganda pada tahun 2010 untuk komoditas ubi jalar, ubi kayu, kacang tanah, kedelai dan kacang-kacangan lainnya tersebut masing-masing 1,$52 ; 1,66 ; 1,60 ; 1,89$; dan 1,71. Artinya, bahwa kemampuan komoditas tersebut dalam penciptaan output yang diakibatkan oleh perubahan permintaan akhir lebih dari 50\% pada setiap perubahan satu satuan permintaan akhir, serta lonjakan kemampuan penciptaan output dalam kurun waktu lima tahun berkisar antara $34-43 \%$ dari setiap tambahan perubahan permintaan akhir.

Begitu juga kemampuan komoditas tersebut dalam penciptaan nilai tambah komoditas tersebut memiliki kemampuan yang lebih tinggi dibanding dengan lainnya dan mengalami peningkatan pada tahun 2010 dibanding dengan tahun 2005. Angka pengganda nilai tambah pada tahun 2010 untuk komoditas ubi jalar, ubi kayu, kacang tanah, kedelai dan kacang-kacangan lainnya masing-masing adalah 1,$33 ; 1,45 ; 1,42 ; 1,75$; dan 1,51 , sedangkan perubahannya masing-masing adalah 0,$26 ; 0,28 ; 0,21 ; 0,43$; dan 0,25 .

Hal yang menarik untuk diperhatikan adalah bahwa kendatipun komoditas tersebut bukan merupakan prioritas nasional. Namun, dalam sistem perekonomian Indonesia mampu menciptakan output dan nilai tambah yang cukup tinggi. Komoditas tersebut seperti kedelai dan kacang-kacangan yang merupakan bahan baku industri tahu, tempe, serta kecap yang dibutuhkan secara masal oleh masyarakat di perdesaan. Sementara itu, untuk ubi jalar dan ubi kayu sudah mulai tumbuh industri terkait sebagai bahan baku industri lainnya, sehingga berkembang industri pengolahan ubi jalar menjadi tepung, pasta, mie serta ubi kayu berkembang industri tapioka, gaplek, tepung casava dan sebagai bahan baku industri lain seperti industri lem, pakan ternak, dan industri makanan (kerupuk, mie, aneka kue). Dengan demikian, bahwa komoditas yang memiliki kemampuan penciptaan output dan nilai tambah dalam sistem ekonomi Indonesia adalah ubi jalar, ubi kayu, kacang tanah, kedelai dan kacang-kacangan lainnya.

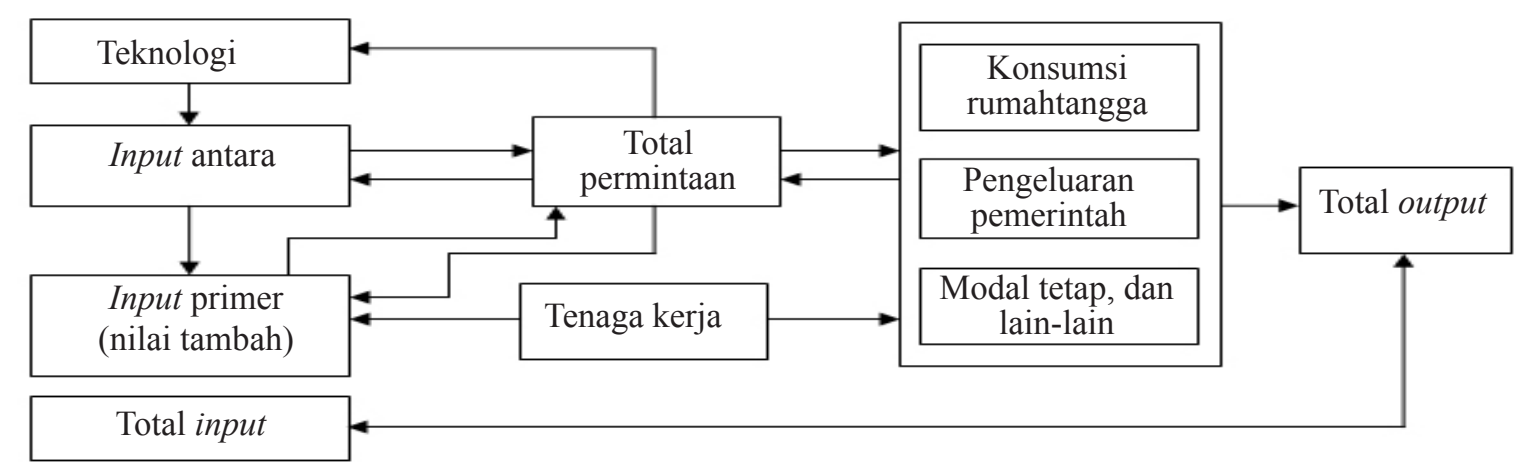

Gambar 1. Kerangka pemikiran penelitian 
Tabel 1. Perubahan angka pengganda output dan nilai tambah, 2005-2010

\begin{tabular}{|c|c|c|c|c|c|c|c|}
\hline \multirow{2}{*}{\multicolumn{2}{|c|}{ Sektor/Komoditas }} & \multicolumn{3}{|c|}{ Pengganda output } & \multicolumn{3}{|c|}{ Pengganda nilai tambah } \\
\hline & & 2005 & 2010 & Perubahan & 2005 & 2010 & Perubahan \\
\hline \multicolumn{8}{|c|}{ Tanaman Pangan dan hortikultura } \\
\hline & Padi & 1,45 & 1,63 & 0,18 & 1,37 & 1,40 & 0,03 \\
\hline & Jagung & 1,40 & 1,56 & 0,16 & 1,30 & 1,37 & 0,07 \\
\hline & Ubi jalar & 1,09 & 1,52 & 0,43 & 1,07 & 1,33 & 0,26 \\
\hline & Ubi kayu & 1,24 & 1,66 & 0,42 & 1,17 & 1,45 & 0,28 \\
\hline & Umbi-umbian lainnya & 1,20 & 1,44 & 0,24 & 1,15 & 1,28 & 0,13 \\
\hline & Kacang tanah & 1,26 & 1,60 & 0,34 & 1,21 & 1,42 & 0,21 \\
\hline & Kedelai & 1,40 & 1,89 & 0,49 & 1,32 & 1,75 & 0,43 \\
\hline 008 & Kacang-kacangan lainnya & 1,34 & 1,71 & 0,37 & 1,26 & 1,51 & 0,25 \\
\hline 009 & Padi-padian dan bahan makanan lainnya & 1,31 & 1,49 & 0,18 & 1,19 & 1,27 & 0,08 \\
\hline 010 & Sayur-sayuran & 1,29 & 1,59 & 0,30 & 1,24 & 1,36 & 0,12 \\
\hline & Buah-buahan & 1,20 & 1,48 & 0,28 & 1,13 & 1,29 & 0,16 \\
\hline \multicolumn{8}{|c|}{ Tanaman Perkebunan } \\
\hline & Tebu & 1,52 & 2,00 & 0,48 & 1,44 & 1,76 & 0,32 \\
\hline 013 & Tembakau & 1,98 & 2,16 & 0,18 & 1,96 & 1,92 & $(0,04)$ \\
\hline 014 & Tanaman serat & 1,22 & 1,53 & 0,31 & 1,13 & 1,32 & 0,19 \\
\hline 015 & Hasil perkebunan lainnya & 1,79 & 1,87 & 0,08 & 1,55 & 1,52 & $(0,03)$ \\
\hline 018 & Karet & 1,54 & 1,98 & 0,44 & 1,61 & 1,60 & $(0,01)$ \\
\hline 019 & Kelapa & 1,38 & 1,64 & 0,26 & 1,26 & 1,37 & 0,11 \\
\hline 020 & Kelapa sawit & 1,72 & 2,07 & 0,35 & 1,55 & 1,74 & 0,19 \\
\hline 021 & Kopi & 1,68 & 1,86 & 0,18 & 1,57 & 1,54 & $(0,03)$ \\
\hline 022 & Teh & 1,37 & 2,06 & 0,69 & 1,29 & 1,68 & 0,39 \\
\hline 023 & Kakao & 1,38 & 1,71 & 0,33 & 1,26 & 1,44 & 0,18 \\
\hline 024 & Cengkeh & 1,33 & 1,71 & 0,38 & 1,23 & 1,42 & 0,19 \\
\hline 025 & Jambu mete & 1,24 & 1,67 & 0,43 & 1,16 & 1,38 & 0,22 \\
\hline \multicolumn{8}{|c|}{ Ternak dan Hasilnya } \\
\hline 026 & Ternak dan hasil-hasilnya kecuali susu segar & 1,46 & 2,14 & 0,68 & 1,37 & 1,70 & 0,33 \\
\hline 027 & Susu segar & 1,73 & 2,25 & 0,52 & 1,72 & 1,87 & 0,15 \\
\hline 028 & Unggas dan hasil-hasilnya & 1,89 & 2,34 & 0,45 & 2,10 & 2,05 & $(0,05)$ \\
\hline 029 & Hasil pemeliharaan hewan lainnya & 1,39 & 2,06 & 0,67 & 1,37 & 1,62 & 0,25 \\
\hline
\end{tabular}

Pada komoditas tanaman perkebunan dalam penciptaan output perubahannya menunjukkan positif artinya bahwa kemampuan komoditas perkebunan dalam penciptaan output terjadi peningkatan pada tahun 2010 dibanding tahun 2005. Komoditas yang mengalami peningkatan tertinggi adalah komoditas teh, tebu, karet, jambu mete, dan cengkeh, masing-masing angka pengganda pada tahun 2010 adalah 2,06; 2,00; 1,98; 1,67 dan 1,71. Besarnya perubahan selama kurun eaktu 5 tahun masing-masing adalah : 0,$69 ; 0,48 ; 0,44$; 0,43; dan 0,38. Hasil peneltian Fahriyah et al. (2012) menunjukan bahwa pengganda output perkebunan tebu sebesar 1,14 dan menduduki peringkat ke 26 dari 40 sektor.
Untuk komoditas perkebunan dari lima komoditas yang mengalami peningkatan kemampuan penciptaan output ternyata hanya 3 komoditas yang memiliki kemampuan dalam penciptaan nilai tambah, diantaranyanya adalah teh, tebu, dan jambu mete dengan angka pengganda nilai tambah pada 2010 masing-masing 1,68; 1,76 dan 1,38 . Kemampuan penciptaan nilai tambah pada kelompok komoditas perkebunan perubahan tertinggi adalah pada komoditas teh dan tebu yakni masingmasing perubahannya 0,39 dan 0,32 . Namun, jika dibandingkan dengan penciptaan nilai tambah pada indutsri pengolahan tebu tetap bahwa kemampuan penciptaan nilai tambah pada perkebunan tebu lebih rendah, temuan ini sejalan dengan hasil peneltiian (Fahriyah et al. 2012). Sedangkan untuk karet bahkan terjadi penurunan kapasitas penciptaan nilai tambah 
dengan perubahannya minus $-0,01$ pada 2010 dibanding dengan 2005. Penurunan kapasitas penciptaan nilai tambah pada komoditas karet disebabkan beberapa faktor berikut: (a) tekanan harga karet dunia, sehingga menurunkan kinerja agribsinis karet domestik; (b) desakan karet sintetik sehingga mempengarui harga karet alam. Komditas lain pada perkebunan yang terjadi penurunan kapasitas penciptaan nilai tambah terjadi pada komoditas tembakau dan kopi, masingmasing minus $-0,04$ dan $-0,03$. Hal ini diduga untuk tembakau adalah sebagai akibat dari meluasnya kampanye anti tembakau dari negara-negara yang sudah memperhatikan kesehatan dan diperkuat dengan adanya ratifikasi konvensi kerangka pengendalian tembakau sehingga berdampak terhadap ekonomi tembakau di Indonesia (Hadi dan Friyatno, 2008).

Pada komoditas pertenakan, secara umum masih menunjukkan kemampuan dalam menciptakan output dengan pengganda output lebih besar dari 2,00, sedangkan yang paling tinggi adalah usaha ternak unggas dan hasilnya dan yang kedua usaha susu segar dengan angka pengganda masing-masing 2,34 dan 2,25; sedangkan yang memiliki peningkatan kemampuan dalam penciptaan output adalah usahaternak diluar susu dan pemeliharaan hewan berubahan pengganda masing-masing adalah 0,68 dan 0,67. Hal yang menarik perhatian di sini adalah bahwa untuk usaha ternak unggas dalam kurun waktu lima tahun terjadi penurunan kinerja ekonominya. Hal ini dicirikan oleh terjadinya penurunan kemampuan penciptaan nilai tambah sebesar minus 0,05 . Penurunan kinerja ekonomi perunggasan terkait dengan masalah ketersediaan pakan ternak, terutama terkait dengan masalah pasokan jagung.

\section{Sumber Pengganda Output}

Angka pengganda output suatu sektor/komoditas berasal dari beberapa sumber, yakni dari aktivitas sektor/komoditas itu sendiri maupun dari sektor lainnya. Sumbangan pembentukan output bisa berasal dari: (a) masukan awal akibat perubahan permintaan akhir disebut initial impact, (b) keterkaitan koefisien teknis disebut fisrt impact, (c) keterkaitan industri disebut induce impact, dan (d) karena peningkatan konsumsi akibat dari peningkatan pendapatan disebut consumption impact.
Sumber penciptaan output untuk komoditas tanaman pangan adalah pada kedelai, kacang tanah, ubi jalar dan ubi kayu seperti terlihat pada Tabel 2. Dari hasil analisis tersebut menunjukkan bahwa sumber pengganda output untuk kedelai adalah $60 \%(1,134)$ berasal dari aktivitas kedelai itu sendiri termasuk di dalamnya nilai awal dari perubahan permintaan akhir (intinial impack) sebesar 1,0 dan 0,134 berasal dari first impack, induce impack, dan consumption impack. Sedangkan 40\% lainnya berasal dari keterkaitan dengan sektor lain baik langsung maupun tidak langsung, yaitu berasal dari sektor pupuk, jasa pertanian, barang hasil kilang minyak, minyak bumi, penggilingan padi, padi, gas bumi, rokok dan unggas, masing-masing pangsanya secara berurutan $2,76 \% ; 2,64 \% ; 1,18 \% ; 0,93 \% ; 0,90 \%$; $0,71 \% ; 0,42 \% ; 0,41 \%$ dan $0,39 \%$, sedangkan sisanya untuk mencapai $40 \%$ berasal lebih dari 80 sektor yang pangsanya kurang dari $0,39 \%$.

Sumber pengganda output untuk kacang tanah adalah $67,35(1,0776)$ berasal dari aktivitas kacang tanah itu sendiri termasuk di dalamnya nilai awal dari perubahan permintaan akhir (intinial impack) sebesar 1,0 dan 0,0776 berasal dari first impack, induce impack, dan consumption impack. Sementara itu, 36,65\% lainnya berasal dari keterkaitan dengan sektor lain baik langsung maupun tidak langsung, yaitu berasal dari sektor jasa pertanian, pupuk, barang hasil kilang minyak, penggilingan padi, padi, minyak bumi, rokok, unggas, dan ikan masing-masing pangsanya secara berurutan $1,77 \% ; 1,32 \% ; 0,99 \% ; 0,84 \% ; 0,67 \%$; $0,56 \% ; 0,39 \% ; 0,38 \%$ dan $0,36 \%$, sedangkan sisanya untuk mencapai $40 \%$ berasal lebih dari 80 sektor yang pangsanya kurang dari $0,36 \%$.

Penjelasan yang sama untuk komoditas ubi jalar dan ubi kayu sumber pengganda dari dirinya sendiri adalah $69,86 \%$ dan $62,90 \%$, berarti sekitar $30,14 \%$ dan $37,1 \%$ berasal dari sektor terkait lainnya. Untuk ubi jalar, yakni dari sektor jasa pertanian, hasil kilang minyak, pupuk, penggilangan padi, padi, minyak bumi, rokok, unggas dan ikan dengan pangan dari tertinggi $1,17 \%-0,39 \%$. Sumber pengganda ubi kayu dari sektor terkait lainnya adalah sektor jasa pertanian, pupuk, kilang minyak, penggilingan padi, minyak bumi, padi, rokok, unggas dan gas bumi, dengan pangsa dari yang tertinggi 2,51\% $-0,38 \%$. 
Tabel 2. Faktor penentu pembentukan angka pengganda output tanaman pangan

\begin{tabular}{|c|c|c|c|}
\hline Komoditas/Sektor & Pengganda & $(\%)$ & Rank \\
\hline \multicolumn{4}{|l|}{ Kedelai } \\
\hline Kedelai & 1,1340 & 60,00 & 1 \\
\hline Pupuk & 0,0522 & 2,76 & 2 \\
\hline Jasa pertanian, kehutanan dan perikanan & 0,0499 & 2,64 & 3 \\
\hline Barang-barang hasil kilang minyak dan gas bumi & 0,0223 & 1,18 & 4 \\
\hline Minyak bumi & 0,0176 & 0,93 & 5 \\
\hline Hasil Penggilingan padi dan penyosohan beras & 0,0170 & 0,90 & 6 \\
\hline Padi & 0,0134 & 0,71 & 7 \\
\hline Gas bumi dan panas bumi & 0,0079 & 0,42 & 8 \\
\hline Rokok & 0,0077 & 0,41 & 9 \\
\hline Unggas dan hasil-hasilnya & 0,0074 & 0,39 & 10 \\
\hline \multicolumn{4}{|l|}{ Kacang Tanah } \\
\hline Kacang tanah & 1,0776 & 67,350 & 1 \\
\hline Jasa pertanian, kehutanan dan perikanan & 0,0283 & 1,770 & 2 \\
\hline Pupuk & 0,0211 & 1,320 & 3 \\
\hline Barang-barang hasil kilang minyak dan gas bumi & 0,0158 & 0,990 & 4 \\
\hline Hasil penggilingan padi dan penyosohan beras & 0,0134 & 0,840 & 5 \\
\hline Padi & 0,0107 & 0,670 & 6 \\
\hline Minyak bumi & 0,0090 & 0,560 & 7 \\
\hline Rokok & 0,0062 & 0,390 & 8 \\
\hline Unggas dan hasil-hasilnya & 0,0061 & 0,380 & 9 \\
\hline Ikan & 0,0058 & 0,360 & 10 \\
\hline \multicolumn{4}{|l|}{ Ubi Jalar } \\
\hline Ubi jalar & 1,0619 & 69,86 & 1 \\
\hline Jasa pertanian, kehutanan \& perikanan & 0,0178 & 1,170 & 2 \\
\hline Barang hasil kilang minyak \& gas bumi & 0,0143 & 0,940 & 3 \\
\hline Pupuk & 0,0138 & 0,910 & 4 \\
\hline Penggilingan padi \& penyosohan beras & 0,0137 & 0,900 & 5 \\
\hline Padi & 0,0108 & 0,710 & 6 \\
\hline Minyak bumi & 0,0070 & 0,460 & 7 \\
\hline Rokok & 0,0065 & 0,430 & 8 \\
\hline Unggas dan hasil-hasilnya & 0,0061 & 0,400 & 9 \\
\hline Ikan & 0,0059 & 0,390 & 10 \\
\hline \multicolumn{4}{|l|}{ Ubi Kayu } \\
\hline Ubi kayu & 1,0441 & 62,90 & 1 \\
\hline Jasa pertanian, kehutanan, perikanan & 0,0417 & 2,510 & 2 \\
\hline Pupuk & 0,0332 & 2,000 & 3 \\
\hline Barang hasil kilang minyak \& gas bumi & 0,0183 & 1,100 & 4 \\
\hline Penggilingan padi \& penyosohan beras & 0,0144 & 0,870 & 5 \\
\hline Minyak bumi & 0,0123 & 0,740 & 6 \\
\hline Padi & 0,0115 & 0,690 & 7 \\
\hline Rokok & 0,0068 & 0,410 & 8 \\
\hline Unggas dan hasil-hasilnya & 0,0063 & 0,380 & 9 \\
\hline Gas bumi dan panas bumi & 0,0063 & 0,380 & 10 \\
\hline
\end{tabular}


Hal yang menarik perhatian di sini adalah bahwa sumbangan sumber penggada output untuk masingmasing komoditas urutannya sangat tergantung dari sejauhmana tingkat intensifikasi dari komoditas tersebut, semakin intensif sistem pengelolaannya semakin tinggi pangsa dari sumber terkait lainnya terutama dalam penggunaan input, seperti sektor pupuk, jasa pertanian, dan gas. Setelah itu baru tergantung kepada sejauhmana komoditas tersebut digunakan oleh sektor lain sebagai bahan baku/input terutama sektor manufaktur yang berbahan baku komoditas hasil pertanian.

Untuk komoditas perkebunan sumber pengganda output ditampilkan pada 2 komoditas yang memiliki kemampuan penciptaan output dan nilai tambah tinggi, yaitu pada teh dan tebu, seperti yang tertera pada Tabel 3 . Untuk komoditas perkebunan sumber penggada output agak berbeda dengan komoditas tanaman pangan. Hal ini disebabkan pada komoditas perkebunan ini terkait dengan pengolahan seperti teh dan tebu, jadi setiap terjadi peningkatan permintaan akhir, maka sektor lain yang bergerak adalah pengolahan, karena teh dan tebu tidakbisadikonsumsilangsung, danjenispengolahannya sebagian besar di Indonesia adalah termasuk industri menengah dan besar. Dari data tersebut menunjukkan bahwa untuk komoditas teh angka pengganda output $50,14 \%$ berasal dari kegiatan pada komoditas teh dan sisanya 40,86\% dari sektor lainnya yang terkait. Pangsa terbesar menyebar dari sektor logam dasar bukan besi, jasa pertanian, hasil kilang minyak, penggilingan padi, padi, pupuk, rokok, minyak bumi dan barang-barang dari plastik, dengan pangsa masing-masing : 26,78\%; $1,95 \% ; 1,73 \% ; 1,45 \% ; 1,15 \% ; 0,75 \% ; 0,69 \% ; 0,65 \%$ dan $0,63 \%$.

Begitu pula untuk komoditas tebu, sumber pengganda berasal dari aktivitas tebu sendiri sebesar 54,48\% dan sisanya berasal dari sektor lain terkait, yakni dari sektor logam dasar bukan besi, pupuk, minyak bumi, hasil kilang minyak, penggilingan padi, pestisida, padi, kimia dasar dan barang galian lain, dengan pangsa masing-masing $22,63 \% ; 4,77 \% ; 1,43 \% ; 1,42 \% ; 1,05 \%$; $0,92 \% ; 0,83 \% ; 0,60 \%$ dan $0,56 \%$. Oleh karena itu, pengelolaan tebu lebih intensif dibandingkan teh maka sektor terkaitnya lebih banyak dengan sektor-sektor penyedia sarana produksi seperti pupuk, pestisida, dan kimia dasar sebagai bahan baku pestisida.

Tabel 3. Sumber pengganda output komoditas perkebunan

\begin{tabular}{|c|c|c|c|}
\hline Komoditas & Pengganda & $(\%)$ & Rank \\
\hline \multicolumn{4}{|l|}{ Teh } \\
\hline Teh & 1,0329 & 50,14 & 1 \\
\hline Logam dasar bukan besi & 0,5517 & 26,78 & 2 \\
\hline Jasa pertanian, kehut \& perikanan & 0,0402 & 1,95 & 3 \\
\hline Barang hasil kilang minyak dan gas bumi & 0,0356 & 1,73 & 4 \\
\hline Hasil penggilingan padi dan penyosohan beras & 0,0299 & 1,45 & 5 \\
\hline Padi & 0,0237 & 1,15 & 6 \\
\hline Pupuk & 0,0155 & 0,75 & 7 \\
\hline Rokok & 0,0142 & 0,69 & 8 \\
\hline Minyak bumi & 0,0134 & 0,65 & 9 \\
\hline Barang-Barang dari Plastik & 0,0130 & 0,63 & 10 \\
\hline \multicolumn{4}{|l|}{ Tebu } \\
\hline Tebu & 1,0896 & 54,48 & 1 \\
\hline Logam dasar bukan besi & 0,4526 & 22,63 & 2 \\
\hline Pupuk & 0,0954 & 4,77 & 3 \\
\hline Minyak bumi & 0,0286 & 1,43 & 4 \\
\hline Barang Hasil kilang minyak dan gas bumi & 0,0284 & 1,42 & 5 \\
\hline Hasil penggilingan padi dan penyosohan & 0,0210 & 1,05 & 6 \\
\hline Pestisida & 0,0184 & 0,92 & 7 \\
\hline Padi & 0,0166 & 0,83 & 8 \\
\hline Kimia dasar kecuali pupuk & 0,0120 & 0,60 & 9 \\
\hline Barang galian segala jenis & 0,0112 & 0,56 & 10 \\
\hline
\end{tabular}


Menurut IRSA (2009) yang juga diacu (Ilham et al. 2015), produk daging dan jerohannya terkait dengan 66 industri lain, sedangkan produk daging olahan dan awetan lain terkait dengan 54 industri lain. Angka pengganda output industri produk daging dan jerohannya bernilai 1,89 dan untuk produk daging olahan dan awetan 2,34. Artinya, jika permintaan pada industri ini meningkat masing-masing sebesar Rp 1,00 maka output secara nasional akan meningkat masingmasing sebesar Rp1,89 dan Rp2,34.

Sumber pengganda komoditas peternakan, yaitu usaha ternak dan hasilnya dan usaha ternak susu, secara rinci tertera pada Tabel 4. Dari hasil analisis data tersebut dapat dijelaskan bahwa untuk usaha ternak diluar susu sumber penggada terbesa $(47,01 \%)$ berasal dari usaha ternak itu sendiri, sedangkan sisanya sekitar 52,99\% berasal dari sektor terkait. Pada usaha ternak ini tidak secara jelas jenis yang dipelihara sumber dari sektor pakan olahan lebih rendah dari usaha ternak susu yakni $7,08 \%$ dan sumber pengganda sektor lainnya adalah padi, jagung, penggilingan padi, hasil kilang minyak, tepung lainya, minyak hewan, unggas lainnya dan ikan masing-masing pangsanya adalah 1,92\%; $1,62 \% ; 1,56 \% ; 1,33 \% ; 0,87 \% ; 0,72 \% ; 0,72 \%$; dan $0,65 \%$. Pada usaha ternak susu sumber pengganda output dari sektor itu sendiri lebih rendah yakni hanya $44,48 \%$, sedangkan dari sektor lainnya yang tertinggi adalah dari makanan olahan hewan mencapai $10,65 \%$. Adalah logis bahwa sektor usaha susu faktor utamanya adalah pakan olahan, sedangkan dari sektor lainnya adalah jagung, padi, penggilingan padi, hasil kilang minyak, tepung lainnya, minyak hewan, unggas dan ikan, masing-masing pangsanya $3,32 \% ; 2,18 \% ; 1,44 \%$; $1,22 \% ; 1,14 \% ; 0,80 \% ; 0,62 \%$ dan $0,61 \%$.

\section{Keterkaitan ke Belakang dan ke Depan}

Kemampuan suatu sektor atau komoditas dalam penciptaan output dan nilai tambah ditentukan juga oleh sejauh mana keterkaitan suatu sektor ke belakang dan kedepan. Keterkaitan ke belakang dan ke depan dari komoditas tanaman pangan, perkebunan dan peternakan tertera pada Tabel 5 .

Tabel 4. Sumber pengganda output sektor peternakan

\begin{tabular}{lccc}
\hline \multicolumn{1}{c}{ Komoditas } & Pengganda & $(\%)$ & Rank \\
\hline Usaha Ternak & & & \\
Ternak dan hasilnya kecuali Susu Segar & 1,0060 & 47,01 & 1 \\
Makanan hewan olahan & 0,1515 & 7,08 & 2 \\
Padi & 0,0411 & 1,92 & 3 \\
Jagung & 0,0347 & 1,62 & 4 \\
Penggilingan padi dan penyosohan & 0,0334 & 1,56 & 5 \\
Barang hasil kilang minyak \& gas Bumi & 0,0285 & 1,33 & 6 \\
Tepung lainnya & 0,0186 & 0,87 & 7 \\
Minyak hewani dan minyak nabati & 0,0154 & 0,72 & 8 \\
Unggas dan hasil-hasilnya & 0,0154 & 0,72 & 9 \\
Ikan & 0,0139 & 0,65 & 10 \\
Usaha Susu & & & \\
Susu segar & 1,0008 & 44,48 & 1 \\
Makanan hewan olahan & 0,2396 & 10,65 & 2 \\
Jagung & 0,0522 & 2,32 & 3 \\
Padi & 0,0491 & 2,18 & 4 \\
Penggilingan padi dan penyosohan & 0,0324 & 1,44 & 5 \\
Barang hasil kilang minyak \& gas Bumi & 0,0275 & 1,22 & 6 \\
Tepung lainnya & 0,0257 & 1,14 & 7 \\
Minyak hewani dan minyak Nabati & 0,0180 & 0,80 & 8 \\
Unggas dan hasil-hasilnya & 0,0140 & 0,62 & 9 \\
Ikan & 0,0137 & 0,61 & 10 \\
\hline
\end{tabular}


Tabel 5. Keterkaitan ke belakang (backward linkage) dan ke depan (forward linkage)

\begin{tabular}{|c|c|c|c|c|c|c|}
\hline \multirow{2}{*}{ Sektor/Komoditas } & \multicolumn{3}{|c|}{ Backward Linkage } & \multicolumn{3}{|c|}{ Backward Linkage } \\
\hline & 2005 & 2010 & Perubahan & 2005 & 2010 & Perubahan \\
\hline \multicolumn{7}{|l|}{ Tanaman Pangan dan Hortikultura } \\
\hline Padi & 0,769 & 0,759 & $(0,009)$ & 1,325 & 1,351 & 0,026 \\
\hline Jagung & 0,743 & 0,727 & $(0,017)$ & 1,189 & 1,390 & 0,200 \\
\hline Ubi jalar & 0,580 & 0,709 & 0,129 & 0,947 & 1,229 & 0,282 \\
\hline Ketela pohon & 0,656 & 0,773 & 0,116 & 1,065 & 1,230 & 0,165 \\
\hline Umbi-umbian lainnya & 0,634 & 0,672 & 0,038 & 1,029 & 1,179 & 0,150 \\
\hline Kacang Tanah & 0,671 & 0,744 & 0,073 & 1,015 & 1,181 & 0,166 \\
\hline Kedelai & 0,740 & 0,880 & 0,140 & 1,205 & 1,475 & 0,270 \\
\hline Kacang-kacang lainnya & 0,709 & 0,797 & 0,089 & 1,198 & 1,269 & 0,071 \\
\hline Padi2an \& bahan makanan lainnya & 0,697 & 0,692 & $(0,005)$ & 1,841 & 1,019 & $(0,822)$ \\
\hline Sayur-sayuran & 0,684 & 0,739 & 0,055 & 1,060 & 1,145 & 0,086 \\
\hline Buah-buahan & 0,634 & 0,691 & 0,057 & 0,974 & 0,875 & $(0,099)$ \\
\hline \multicolumn{7}{|l|}{ Tanaman Perkebunan } \\
\hline Tebu & 0,808 & 0,930 & 0,122 & 1,525 & 1,491 & $(0,033)$ \\
\hline Tembakau & 1,051 & 1,005 & $(0,046)$ & 1,238 & 1,263 & 0,025 \\
\hline Hasil tanaman serat & 0,647 & 0,713 & 0,067 & 0,624 & 0,931 & 0,307 \\
\hline Hasil perkebunan lainnya & 0,950 & 0,872 & $(0,077)$ & 0,945 & 0,694 & $(0,251)$ \\
\hline Karet & 0,817 & 0,923 & 0,105 & 0,927 & 0,814 & $(0,112)$ \\
\hline Kelapa & 0,733 & 0,766 & 0,033 & 1,073 & 1,107 & 0,034 \\
\hline Kelapa sawit & 0,909 & 0,963 & 0,054 & 1,026 & 0,808 & $(0,218)$ \\
\hline Kopi & 0,893 & 0,866 & $(0,027)$ & 0,848 & 0,732 & $(0,116)$ \\
\hline Teh & 0,726 & 0,957 & 0,231 & 1,121 & 1,351 & 0,230 \\
\hline Kakao & 0,734 & 0,794 & 0,061 & 0,482 & 0,876 & 0,394 \\
\hline Cengkeh & 0,708 & 0,795 & 0,087 & 1,157 & 1,087 & $(0,070)$ \\
\hline Jambu mete & 0,658 & 0,777 & 0,120 & 1,115 & 0,754 & $(0,361)$ \\
\hline \multicolumn{7}{|l|}{ Ternak dan Hasilnya } \\
\hline Ternak \& Hasilnya kecuali susu & 0,776 & 0,997 & 0,221 & 1,273 & 0,840 & $(0,434)$ \\
\hline Susu segar & 0,918 & 1,047 & 0,129 & 1,177 & 1,178 & 0,001 \\
\hline Unggas dan hasil-hasilnya & 1,002 & 1,090 & 0,088 & 1,170 & 1,159 & $(0,011)$ \\
\hline Hasil pemeliharaan hewan lainnya & 0,739 & 0,960 & 0,221 & 0,886 & 0,561 & $(0,325)$ \\
\hline
\end{tabular}

Dari Tabel 5 dapat dijelaskan bahwa secara umum angka keterkaitan ke belakang adalah kurang dari 1. Artinya, bahwa sektor primer tersebut dibawah rata-rata keterkaitan sektor sekunder seperti sektor industri, kecuali tembakau, susu segar, serta unggas dan hasilnya. Namun, keterkaitan ke belakang kurang dari 1 tampak ada kenaikan dari tahun 2010 dibanding dengan tahun 2005. Hal ini dicontohkan pada kelompok tanaman pangan adalah ubi jalar, ubi kayu, dan umbi-umbian lainnya, kacang tanah, kedelai dan sayuran. Artinya, untuk komoditas yang positif berarti terjadi peningkatan dalam menggunaan input yang lebih beragam dan lebih intensif dibanding lima tahun sebelumnya. Sementara itu, untuk tanam padi dan jagung tampak terjadi pengurangan ketergantungan faktor input, hal ini diduga bahwa upaya pemerintah dalam penggunaan faktor produksi khususnya program mandiri benih, rasionalisasi penggunaan pupuk oleh petani dan pupuk organik.

Pada kelompok tanaman pangan keterkaitan ke depannya lebih tinggi dan di atas rata-rata, kecuali komoditas buah-buahan. Dalam lima tahun telah terjadi peningkatan keterkaitan ke depan, kecuali pada komoditas padi-padian dan buah-buahan. Hal ini menunjukkan bahwa sebagian besar komoditas tanaman pangan, hilirisasi produk sudah mulai berjalan yang tertinggi adalah ubi jalar, ketela pohon dan kedelai, masing-masing kenaikan keterkaitan ke depannya adalah 0,$282 ; 0,165 ;$ dan 0,270 dengan 
pengganda keterkaitan masing-masing sebesar 1,229; 1,230; dan 1,475. Untuk komoditas perkebunan, terjadi peningkatan keterkaitan ke belakang yang cukup tinggi adalah tebu, karet, teh dan jambu mete dengan perubahan masing-masing 0,$122 ; 0,105 ; 0,231$; dan 0,120 , walaupun keterkaitan kebelakangnya relatif rendah. Keterkaitan ke depan yang terjadi perubahan tinggi adalah hasil tanaman serat, teh dan kakao. Pada sebagian besar komoditas perkebunan keterkaitan ke depannya mengalami penurunan seperti tebu, karet, kepala sawit, kopi, cengkeh dan jambu mete. Untuk komoditas karet diduga karena terdesak oleh karet sintetik, kelapa sawit dan cengkeh adanya black capaign tentang minyak sawit dan rokok untuk kesehatan, serta tebu terdesak oleh masuknya impor gula rafinasi. Berbeda dengan tanaman pangan pengembangan hilirisasi produk perkebunan lebih terbuka untuk dikembangkan.

Namun demikian, kemampuan penciptaan output dan nilai tambah suatu komoditas juga dapat ditingkatkan melalui kualitas teknologi yang digunakan oleh suatu sektor, misalnya keterkaitan kebelakang dalam hal penggunaan kualitas faktor produksi akan memengaruhi juga kemampuan penciptaan output suatu komoditas atau sektor tertentu. Sejalan dengan kesimpulan Suyanti (2013) dengan menggunakan metode kuantitatif ekonometrik menyimpulkan bahwa untuk meningkatkan produksi hortikultura perlu diupayakan melalui penggunaan faktor input yang berkualitas tinggi.

Konsisten dengan bahasan sebelumnya untuk komoditas peternakan keterkaitan ternak dan hasilnya terjadi perkembangan sebesar 0,221 dan hasil pemeliharaan hewan lainnya sebesar 0,221 , susu segar 0,129 dan unggas sebesar 0,088 . Untuk produk unggas terkait dengan meningkatnya industri pembibitan dan pakan ternak. Sementara itu, keterkaitan ke depannya hanya terjadi pada produk susu yang berkembang yang dipicu berkembangnya industri pengolahan susu.

\section{Implikasi Manajerial}

Implikasi manajerial penting yang dapat ditarik dari tulisan ini adalah pentingnya peran pemerintah dalam mendorong dan memfasilitasi tumbuh kembangnya agroindustri pada sektor atau komoditas yang memiliki kemampuan menciptakan output, nilai tambah, serta memiliki keterkaitan yang kuat baik kebelakang maupun ke depan. Bagi pelaku usaha perlu mengembangkan manajemen rantai pasok pada sektor atau kelompok komoditas tersebut sehingga dapat meningkatkan keterpaduan proses produksi dan antar pelaku usaha sehinga dapat meningkatkan efektivitas dan efisiensi dalam menciptakan output dan nilai tambah produkproduk yang dihasilkan.

\section{KESIMPULAN DAN SARAN}

\section{Kesimpulan}

Dari perspektif ekonomi, ditinjau dari sisi kemampuan penciptaan output, nilai tambah dan keterkaitan antar sektor maka kelompok tanaman pangan yang memiliki kapasitas untuk dijadikan sebagai komoditas agribisnis adalah ubi jalar, ubi kayu kacang tanah dan kacang kedelai. Pada kelompok komoditas perkebunan komoditas yang memiliki peluang sebagai komoditas agribisnis adalah teh, tebu, jambu mete, dan cengkeh. Sementara itu, untuk kelompok peketernakan yang memiliki potensi dijadikan komoditas agribisnis adalah ternak dan hasilnya, serta ternak sapi perah.

Pengebangan hilirisasi produk-produk yang memiliki kemampuan dalam penciptaan output dan nilai tambah, serta memiliki keterkaitan yang kuat baik keterkaitan ke belakang maupun kedepan, disertai dengan promosi produk dapat mendorong semakin kuatnya komoditas tersebut sebagai komoditas agribisnis baik pada komoditas tanaman pangan, hortikultura, perkebunan dan peternakan.

Sumber pengganda output lebih banyak ditentukan oleh kinerja komoditas itu sendiri dan keterkaitan langsung penggunaan input ke belakang dan ke depan. Kecuali jika perkembangan ekonomi sudah mengarah konsumsi masal maka efek domino dari peningkatan permintaan akibat dari meningkatnya pendapatan memberikan efek yang tinggi.

\section{Saran}

Harus menjadi kesadaran pemerintah bahwa selain menetapkan komoditas strategis nasional juga memberikan fokus kepada komoditas yang secara sistem ekonomi memberikan kemampuan penciptaan output dan nilai tambah bagi terbentuknya pendapatan nasional. Komoditas-komoditas yang selama ini dianggap inferior justru jika dikembangkan akan memiliki dukungan terhadap pengembangan ekonomi 
nasional. Sudah sepetutnya bahwa hilirisasi dari setiap komoditas yang dilaksanakan di dalam negeri menjadi prioritas dalam rangka mendongkrak ekonomi nasional, sepertipengembanganindustritepungkompositberbasis umbi-umbian, pengolahan teh, revitalisasi pabrik gula, pengolahan kakao, pengembangan industri susu, serta hasil olahan ternak dapat menggerakkan perekonomian dan meningkatkan nilai tambah yang tinggi.

\section{DAFTAR PUSTAKA}

Ahmed R, Donovan C. 1992. Issues of Infrastructural Development: A Synthesis of the Literature. Washington: International Food Policy Research Institute.

Ajiboye AO, Afolayan O. 2009. The impact of transportation on agricultural production in a developing country: a case of kolanut production in Nigeria. International Journal of Agricultural Economics and Rural Development 2(2): 4957.

Agustian, A. 2012. Pengaruh harga dan infrastruktur terhadap penawaran output, permintaan input dan daya saing usahatani jagung di Jawa Timur dan Jawa Barat [disertasi]. Bogor: Program Doktor. Sekolah Pascasarjana, Institut Pertanian Bogor.

Adefila JO, Bulus JS. 2014. Spatial inequalities in infrastructural development in plateau state, Nigeria. American International Journal of Contemporary Research 4(7): 89-97. http:// www.aijcrnet.com/journals/Vol_4_No_7 July_2014/12.pdf.

BPS. 2015. Teori Penyusunan Input-Output. Jakarta: Badan Pusat Statistik.

Bulmer-Thomas V. 1982. Input-Output Analysis in Developing Countries: Sources, Methods and Applications. New York:John Wiley \& Sons Ltd.

Baharsyah S. 2007. Relevansi Growth with Equaity sebagai Tema 'Tema Perjuangan'. Jakarta.

Chandra DP, Asmara, A. 2010. Analisis peranan dan dampak investasi infrastruktur terhadap perekonomian indonesia: analisis input-output. Jurnal Manajemen dan Agribisnis 7(1): 48-58.

Daryanto A. 1999. Structural change and determinants of agriculture's relative decline. Journal of Agricultural and Resource Socio-Economics, 12(3): 75-94.

Davis J, Goldberg R. 1957. A Concept of Agribusiness. Boston: Harvard University.
Fahriyah, Siregar H, Oktaviani R. 2012. Peranan Industri Gula Dalam Perekonomian Wilayah: Analisis Input-Output Kabupaten Pasuruan. Hal 131-163. Dalam Bayu Krisnamurthi (Eds.) Ekonomi Gula. Jakarta: PT. Gramedia Pustaka Utama.

Gibson J, Olivia S. 2008. The Effect of Infrastructure Access and Quality on Non-farm Enterprises in Rural Indonesia. Working Paper in Economics $17 / 08$.

Hadi PU, Friyatno S. 2008. Peranan sektor tembakau dan industri rokok dalam perekonomian indonesia: analisis tabel I-O tahun 2000. Jurnal Agro Ekonomi 26(1):90-121. https://doi. org/10.21082/jae.v26n1.2008.90-121.

Hartono D, Irawan T, Irawan F. 2010. Infrastructure improvement and its impact on Indonesian economic performance. Working Paper in Economics and Development Studies No. 201008. Center for Economics and Development Studies, Department of Economics, Padjadjaran University.

Hartoyo S. 2013. The impact of rural road rehabilitation on rice productivity and farmers income in Kemang Village, Cianjur, West Java, Indonesia. Journal of International Society for Southeast Asian Agricultural Sciences 19(2):18-29.

Inoni OE, Omotor DG. 2009. Effect of road infrastructure on agricultural output and income of rural households in Delta State, Nigeria. Agricultura Tropica et Subtropica 42(2).

IRSA. 2009. Pengaturan Kebijakan Industri Daging Sapi di Indonesia. Jakarta: Indonesia Research Strategic Analysis.

Ikejiofor IG, Ali A. 2014. The effects of road transport characteristics on the marketing of agricultural produce In Nsukka Lga, Enugu State, Southeastern Nigeria. Innovare Journal and Social Sciences 2(1):1-4.

Ilham N, Saptana, Purwoto A, Supriyatna Y, Nurasa T. 2015. Kajian Pengembangan Industri Peternakan Mendukung Peningkatan Produksi Daging. Bogor: Pusat Sosial Ekonomi dan Kebijakan Pertanian.

Kiprono P, Matsumoto T. 2014. Roads and Farming: The Effect of Infrastructure Improvement on Agricultural Input Use, Farm Productivity and Market Participation in Kenya. Africa: CSAE Conference.

Kassali R, Ayanwale AB, Idowu EO, Williams SB. 2012. Effect of rural transportation system on 
agricultural productivity in Oyo State, Nigeria. Journal of Agriculture and Rural Development in the Tropics and Subtropics 113(1):13-19.

Llanto GM. 2012. The Impact of Infrastructure on Agricultural Productivity. Discussion Paper Series 2012-12. Philippine Institute for Development Studies.

Mille RE, Blair PD. 1985. Input-Output Analysis: Foundations and Extentions. New Jersey: Prentice-Hall, Inc.,

Miernyk WH. 1965. The Elements of Input-Output Analysis. New York: Random House.

Rachman B. 1993. Analisis Keterkaitan Antar Sektor Dalam Perekonomian Wilayah Jawa Barat. Jurnal Agro Ekonomi 12(2): 39-65.

Rachmina D, Daryanto A, Tambunan M, Hakim DB. Impact of infrastructure on profit efficiency of Vegetable Farming in West Java, Indonesia: stochastic frontier approach. Journal of International Society for Southeast Asian Agricultural Sciences 20(1):77-92.

Syafa'at N, Friyatno S. 2000. Peranan Industri Terigu dan yang Berbahan Baku Terigu dalam Penciptaan Nilai Tambah dan Penyerapan Tenaga Kerja. Bogor: Pusat Penelitian Sosial Ekonomi Pertanian.

Suyanti K. 2013. Keterkaitan Produk dan pelaku dalam pengembangan agribisnis hortikultura unggulan di Provinsi Aceh. Jurnal Manajemen dan Agribisnis 10(2): 117-127.

Suryani E, Hartoyo S, Sinaga B M, Sumaryanto. pendugaan elastisitas penawaran output dan permintaan input pada usahatani padi dan jagung: pendekatan multi input-multi output. Jurnal Agro Ekonomi 33(2): 91-107.

Simatupang P. 2015. Transformasi Paradigma Pembangunan Pertanian: Dari Paradigma Agribisnis ke Paradigma Agrobiobisnis Dalam Menumbuhkan Paradigma Aibribisnis: 70 Tahun Profesor Bungaran Saragih. Editor:
Frans BM Dabukke. Ciputat: Pusat Pangan Agribisnis Bekerjasama dengan Gaung Persada (GP) Press.

Simatupang P, Friyatno, S. 2016. Dampak perubahan harga bahan minyak terhadap kinerja sektor pertanian (pendekatan analisis input-output). Journal Agro Ekonomi 34(1): 1-15. https://doi. org/10.21082/jae.v34n1.2016.1-15.

Tapadas CT, Dahl DC. 1999. Supply-driven inputoutput multipliers. Journal of Agricultural Economics 4(10): 35-40.

Terosa CK, Demura, Ito A. 2000. An Input-Output Analysis of the Production Generation and Adjusment Mechanisms of Agriculture Through Time: The Case of Japan, Korea, Taiwan, and the Philippines. In Bustanul A. and H. S. Dillon (eds.). Asian Agriculture Facing The 21st Century. Jakarta: Asian Society of Agricultural Economists.

Ulimwengu J, Funes J, Headey D, You L. 2009. Paving the way for development? the impact of transport infrastructure on agricultural production and poverty reduction in the democratic Republic of Congo. Discussion Paper 00944, International Food Policy Research Institute.

Usman AB. 2014. Analysis of condition of rural road transport in Kwara State, Nigeria. European Scientific Journal 10(5): 288-307. http://eujournal.org/index.php/esj/article/ viewFile/2726/2578.

West GR. 1993. Input-Output for Practitioners. Version 7.1 User's Guide. Australia: Departement of Economics University fo Queensland.

Yoshino N, Nakahigashi M. 2000a. The role of infrastructure in economic development. http:// fs0.econ.mita.keio.ac.jp/staff/dikamiya/pdf00/ seminar/1205.pdf.

Yoshino N, Nakahigashi M. 2000b. Economic effects of infrastructure - japan's experience after world war II. JBIC Review 3 (December 2000): 3-19. 